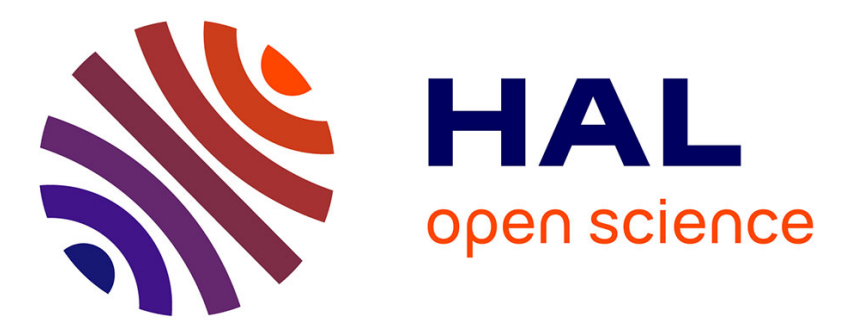

\title{
Nanoindentation Measurements of Biomechanical Properties in Mature and Newly Formed Bone Tissue Surrounding an Implant
}

Romain Vayron, E. Barthel, V. Mathieu, E. Soffer, F. Anagnostou, Guillaume Haiat

\section{To cite this version:}

Romain Vayron, E. Barthel, V. Mathieu, E. Soffer, F. Anagnostou, et al.. Nanoindentation Measurements of Biomechanical Properties in Mature and Newly Formed Bone Tissue Surrounding an Implant. Journal of Biomechanical Engineering, 2012, 134 (2), pp.021007. 10.1115/1.40059811 . hal-00743684

\section{HAL Id: hal-00743684 \\ https://hal.science/hal-00743684}

Submitted on 16 Dec 2019

HAL is a multi-disciplinary open access archive for the deposit and dissemination of scientific research documents, whether they are published or not. The documents may come from teaching and research institutions in France or abroad, or from public or private research centers.
L'archive ouverte pluridisciplinaire HAL, est destinée au dépôt et à la diffusion de documents scientifiques de niveau recherche, publiés ou non, émanant des établissements d'enseignement et de recherche français ou étrangers, des laboratoires publics ou privés. 


\section{Nanoindentation Measurements of Biomechanical Properties in Mature and Newly Formed Bone Tissue Surrounding an Implant}

The characterization of the biomechanical properties of newly formed bone tissue around implants is important to understand the osseointegration process. The objective of this study is to investigate the evolution of the hardness and indentation modulus of newly formed bone tissue as a function of healing time. To do so, a nanoindentation device is employed following a multimodality approach using histological analysis. Coin-shaped implants were placed in vivo at a distance of $200 \mu \mathrm{m}$ from the cortical bone surface, leading to an initially empty cavity of $200 \mu \mathrm{m} * 4.4 \mathrm{~mm}$. Three New Zealand White rabbits were sacrificed after 4, 7, and 13 weeks of healing time. The bone samples were embedded and analyzed using histological analyses, allowing to distinguish mature and newly formed bone tissue. The bone mechanical properties were then measured in mature and newly formed bone tissue. The results are within the range of hardness and apparent Young's modulus values reported in previous literature. One-way ANOVA test revealed a significant effect of healing time on the indentation modulus $(p<0.001, F=111.24)$ and hardness ( $p<0.02, F=3.47)$ of bone tissue. A Tukey-Kramer analysis revealed that the biomechanical properties of newly formed bone tissue (4 weeks) were significantly different from those of mature bone tissue. The comparison with the results obtained in Mathieu et al. (2011, "Micro-Brillouin Scattering Measurements in Mature and Newly Formed Bone Tissue Surrounding an Implant," J. Biomech. Eng., 133, 021006). shows that bone mass density increases by approximately $13.5 \%$ between newly formed bone (7 weeks) and mature bone tissue.

Keywords: bone, implant, osseointegration, nanoindentation, mechanical properties
Romain Vayron

Laboratoire de Modélisation et de Simulation Multi-Echelle,

UMR CNRS 8208,

CNRS, Université Paris Est, 61 Avenue du Général de Gaulle, Créteil 94010, France

Etienne Barthel

Surface du Verre et Interfaces, UMR CNRS 125,

CNRS, Saint-Gobain,

39, quai Lucien Lefranc, Aubervilliers 93303, France

Vincent Mathieu

Laboratoire de Biomécanique Biomatériau Ostéo Articulaire,

CNRS, Université Paris 7 , UMR CNRS 7052

10 Avenue de Verdun, Paris 75010, France

\section{Emmanuel Soffer}

Fani Anagnostou

Laboratoire de Biomécanique Biomatériau Ostéo Articulaire and Department of Periodontology, Service of Odontology,

Pitié Salpetrière Hospital et Hôtel-Dieu Hospital AP-HP,

U.F.R. of Odontology, Université Paris 7 , 5 rue Garancière, 75006 Paris, France

Guillaume Haiat ${ }^{1}$

Laboratoire de Modélisation et de Simulation Multi-Echelle,

UMR CNRS 8208

CNRS, Université Paris Est,

61 Avenue du Général de Gaulle, Créteil 94010, France

e-mail: guillaume.haiat@univ-paris-est.fr

\section{Introduction}

The success of endosseous implant surgical interventions depends on the degree of osseointegration, which is determined by the quantity of bone in direct contact with the implant and by the evolution of the biomechanical properties of newly formed bone tissue at the scale of several micrometers around the implant [1]. Changes in bone material properties around the bone-implant interface (regions located at approximately 100-200 $\mu \mathrm{m}$ from the implant surface) [2] are determinant for the quality of osseointegration. During bone healing, micromotions at a low amplitude may be responsible for biomechanical stimulation of bone remodeling [3]. However, fibrous tissue may develop instead of an osseointegrated interface when there is excessive interfacial

\footnotetext{
${ }^{1}$ Corresponding author
}

micromotion early after surgery $[4,5]$. A better understanding and characterization of the microscopic biomechanical properties of newly formed bone tissue may lead to more accurate prediction of implant osseointegration [6]. Moreover, recent studies by our group [7-11] have recently shown the potentialities of quantitative ultrasound (QUS) techniques to extract information on the boneimplant interface from its ultrasonic response, which depends on newly formed bone tissue biomechanical properties.

Different in vivo studies aiming at investigating the biomechanical properties of newly formed bone tissue have adopted surgical models based on real implants [12,13]. However, a lack of standardization in implant geometries involves variations in the polyaxial mechanical stresses that influence remodelling phenomena. Moreover, working with real implants does not allow either control of the initial gap between bone and implant nor obtaining a clear separation between mature and newly formed bone tissue. Interestingly, considering a planar bone-implant interface using coin-shaped titanium implants leads to standardized conditions from a biomechanical point of view [9], as suggested by Ronold 
et al. [14-18]. As shown in a recent study by our group [7], a dedicated animal model derived from the study of Ronold et al. allows measurements of elastic wave velocity in a bone chamber filled with newly formed bone tissue with a $10 \mu \mathrm{m}$ resolution using micro-Brillouin scattering techniques.

Nanoindentation is a technique widely used to investigate the biomechanical properties of different materials at the microscopic scale [19-27]. In particular, the elastic modulus measured with nanoindentation has been shown to increase with the degree of mineralization of bone tissue [28-30]. Interestingly, nanoindentation has been used to investigate bone tissue properties around implants [12,13,31-34], but it was not possible to clearly relate the indentation modulus with the nature (mature or newly formed) of bone tissue. Moreover, the relationship between healing time and mechanical properties of bone tissue remains unknown.

The present study aims to investigate the evolution of the biomechanical properties of newly formed bone tissue in the vicinity of a titanium implant as a function of healing time. A multimodality experimental approach was used, combining nanoindentation measurements with histological analyses. Three different healing times were considered ( 4,7 , and 13 weeks), and the indentation modulus and hardness were measured both in mature and newly formed bone tissue.

\section{Materials and Methods}

2.1 Implants. Coin-shaped implants $(5 \mathrm{~mm} \pm 0.05 \mathrm{~mm}$ in diameter and $3 \mathrm{~mm} \pm 0.05 \mathrm{~mm}$ in height) were used similarly as in Ref. [7]. Briefly, the implants are of medical grade titanium alloy (Ti-6Al-4V), and their surface was blasted with titanium dioxide $\left(\mathrm{TiO}_{2}\right)$ particles yielding an average $R_{a}$ value of $1.9 \mu \mathrm{m}$ measured by a standard profilometry method (Zygo, Middlefield, CT). Polytetrafluoroethylene (PTFE) caps were placed around the implant in order to create a gap of $200 \mu \mathrm{m}$ (see Fig. 1), which corresponds approximately to typical values obtained in vivo $[35,36]$. Prior to surgery, implants were cleaned, rinsed, and sterilized by autoclaving (1 ATM, $120 \operatorname{degC}, 15 \mathrm{~min}$ ). A total of three implants were used, which corresponds to one implant per rabbit and healing time $(4,7$, and 13 weeks).

2.2 Animal. Three six-month-old female New Zealand White rabbits (Charles River, L'Arbresle, France) were used in this study. The animals were housed in a metal hutch in an environment (ambient temperature $19 \mathrm{deg} \mathrm{C}$ and a humidity of 55\%) in accordance with the requirements of The European Guidelines for Care and Use of Laboratory Animals. Artificial lighting and air conditioning systems were used in the animal housing facility. The animals were fed with commercial food and water was provided ad libitum.

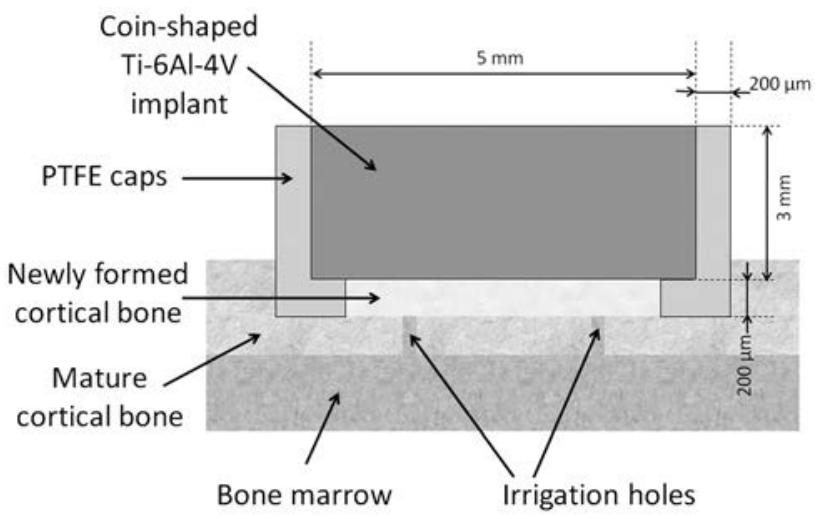

Fig. 1 Schematic representation of the coin-shaped implant model
2.3 Surgical Procedure. The rabbits were anesthetized via intramuscular injection of $0.5 \mathrm{mg} / \mathrm{kg}$ Diazepan (Valium ${ }^{\circledR}$, Roche, Basel, Switzerland), $0.25 \mathrm{mg} / \mathrm{kg}$ metedomidine hydrochloride (Domitor ${ }^{\circledR}$, Virbac, France), and $100 \mathrm{mg} / \mathrm{kg}$ ketamine hydrochloride (Ketalar 500®, Pfizer, France). Prior to surgery, operating sites were shaved and disinfected with betadine. Then, a $5 \mathrm{~cm}$ longitudinal skin incision was made to expose the proximal-anterior part of the tibiae. The lateral reflection of these tissues exposed the underlying periosteum. A medial-anterior incision was made and the periosteum was elevated with a periosteal elevator and retained by a self-retaining retractor, exposing the bone implantation site. A high speed cutter (see Fig. 2) (Tivoly, Saint Etienne, France) was used with physiological saline solution irrigation to level a $5.6 \mathrm{~mm}$ diameter bone surface and to ensure a constant gap between the implant and bone as described previously [14]. A custom made drill guide was used to create four holes $(1.2 \mathrm{~mm}$ in diameter and $2 \mathrm{~mm}$ in height) around the implant. Before the placement of the implant, four holes $(0.9 \mathrm{~mm}$ diameter $)$ were drilled through the leveled cortical bone surface in order to allow blood flow towards the bone-implant interface. The implant was placed and stabilized with orthodontic elastic strings maintained by $1.6 \mathrm{~mm}$ diameter osseointegration screws (Easy Implant, Chavanod, France).

2.4 Sample Preparation and Histology. The first rabbit was euthanized at 4 weeks post implantation using an overdose of Pentobarbital, the second was sacrificed at 7 weeks, and the third was sacrificed at 13 weeks. The implanted tibiae were removed and prepared for histological analysis. Briefly, a procedure described in detail in Refs. [37,38] for non-decalcified histology was used. After fixation in $10 \%$ phosphate-buffered formalin during a period of four weeks, the samples were rinsed in water, dehydrated in ethanol (five baths: $70 \mathrm{deg}, 80 \mathrm{deg}, 90 \mathrm{deg}, 95 \mathrm{deg}$ and three baths : $100 \mathrm{deg}, 24 \mathrm{~h}$ ), cleared in xylene (two baths, $12 \mathrm{~h}$ ) and embedded in methyl methacrylate (three baths of MMA, xylene, dibutyle phthalate and benzoile peroxide for 4 days and the last bath until fully cured). Sections (500 $\mu$ m thick) were prepared from each specimen. For rabbits 1 and 3, one section was considered, which

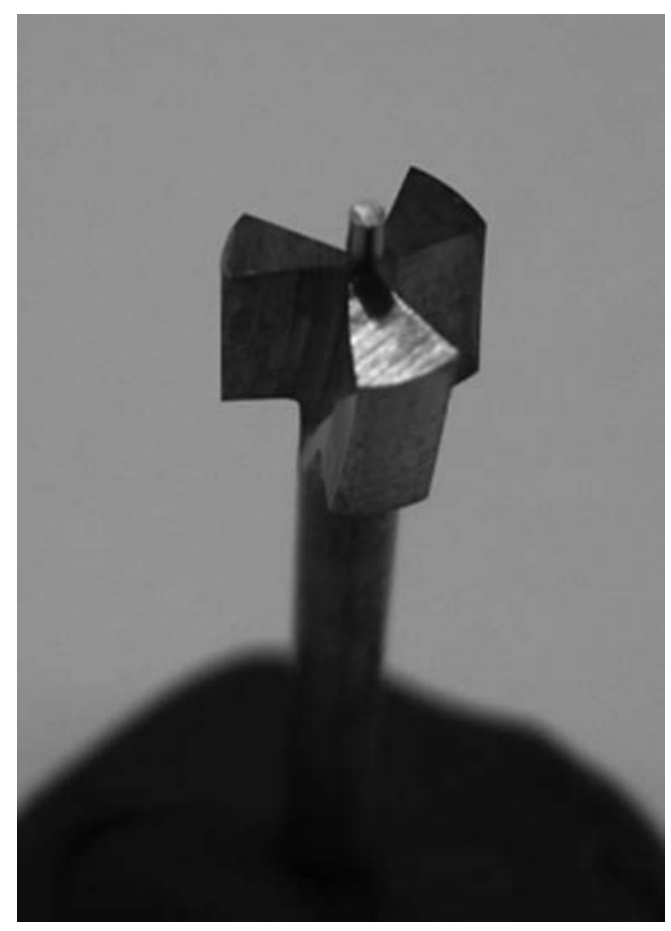

Fig. 2 High speed cutter used with physiological saline solution irrigation to level a $5.6 \mathrm{~mm}$ diameter bone surface and to ensure a constant gap between the implant and bone 
was located in the middle of the implant. For rabbit 2, two sections could be cut in the middle of the implant. Slices were machined perpendicularly to the bone-implant interface and polished to obtain a thickness of $100 \mu \mathrm{m}$ using abrasive papers, Exact Grinding System (Exact Aparatebau GmbH Norderstedt, Germany), and alumina suspensions. The surfaces were then stained with Stevenel's blue and van Gieson picro-fuschin for standard light microscopy. Histological images were analyzed in order to distinguish mature and newly formed bone. Here, we use histological analysis since it is the gold standard in order to assess implant osseointegration. The distinction between mature bone and newly formed tissue is realized based on the coloration of the bone samples. The staining obtained using picro-fuchsin may reveal the degree of mineralization of bone tissue in an empirical manner. Newly formed bone tissue appears brighter than mature bone tissue.

Nanoindentation measurements were performed after histological analysis with the same bone slices. We first looked at the sample under an optical microscope. Then, we determined the location of mature and newly formed bone tissue following the color of bone tissue. Once these areas were identified, we determined in which region could the indent be realized and how many indents could be realized in each bone tissue. The multimodality approach combining nanoindentation and histology was used in order to be certain about the nature of the tested bone tissue for each indent.

2.5 Nanoindentation Measurements. Nanoindentation measurements were performed in this study using a nanoindenter XP System (MTS Nano Instruments, Oak Ridge, TN) with a Berkovich diamond tip. The measurements were performed at room temperature under dry conditions on the bone regions determined by histology and microscopy observation. A post-treatment of the load-displacement curve is performed to derive the bone tissue reduced modulus $E_{r}$ and hardness $H$. The hardness corresponds to plastic deformations and is defined by $[39,40]$

$$
H=\frac{P}{A}
$$

Where $P$ is the maximum load applied by the tip, and $A$ is the corresponding contact surface area. $A$ is determined by

$$
A=\alpha *\left(h_{c}\right)^{2}
$$

where $h_{c}$ is the maximum value of the penetration [41], $\alpha$ is a nondimensional geometrical constant given by $\alpha=\pi * \tan ^{2} \psi$, where $\psi$ is the included angle of an effective cone approximating the pyramidal indenter tip geometry. The value of $\alpha=24.5$ is associated with an ideal Berkovich pyramidal indenter with an included angle $\psi=70.3 \mathrm{deg}$. Both elastic and plastic deformations contribute to the total contact area at peak load [40].

The bone effective indentation modulus $E_{b}$ was determined using the method developed by Oliver and Pharr [39,42], accounting for the effect of the respective contribution of the tip and of the sample. The effective indentation modulus is determined assuming that bone tissue is elastic, isotropic, and homogeneous as follows [19,43]:

$$
\frac{1}{E_{r}}=\frac{\left(1-v_{b}{ }^{2}\right)}{E_{b}}+\frac{\left(1-v_{i}^{2}\right)}{E_{i}}
$$

where $E$ stands for Young's modulus and $\nu$ for Poisson's ratio, the subscript $b$ and $i$ referring to bone sample and indenter tip material, respectively, and $E_{r}$ is reduced modulus. Poisson's ratio $\nu_{b}$ was set arbitrarily to 0.25 , and the elastic properties of the diamond indenter tip were $\nu_{i}=0.07$ and $E_{i}=1141 \mathrm{GPa}$ [44].

To determine the value of $E_{r}$, the continuous stiffness measurement (CSM) technique $[45,46]$ was used by recording stiffness data along with load and displacement data, leading to a direct
Table 1 Numbers of indents realized in mature and newly formed bone tissue samples for different healing times

\begin{tabular}{lccc}
\hline \hline & Rabbit 1 & Rabbit 2 & Rabbit 3 \\
\hline $\begin{array}{l}\text { Healing time } \\
\begin{array}{l}\text { Number of indentations in } \\
\text { newly formed bone tissue }\end{array}\end{array}$ & 4 weeks & 7 weeks & 13 weeks \\
$\begin{array}{l}\text { Number of indentations in } \\
\text { mature bone tissue }\end{array}$ & 70 & 106 & 60 \\
\hline \hline
\end{tabular}

and continuous measure of elastic modulus and hardness as a function of indentation depth $[39,47]$. This method has been shown to be weakly sensitive to thermal drift and to allow an accurate observation of small volume deformation [45]. CSM was performed using a $2 \mathrm{~nm}$ magnitude oscillation with a frequency of $45 \mathrm{~Hz}$ [43].

The calibration of the nanoindenter geometry was performed with a fused silica sample. The locations where the indents were made (maximal penetration of $3 \mu \mathrm{m}$ ) are separated by a distance of $30 \mu \mathrm{m}$ to avoid any interaction between the indents. When the tip reaches the maximum penetration depth of $3 \mu \mathrm{m}$, the load is maintained constant during $150 \mathrm{~s}$ and then decreases at a constant velocity $(100 \mathrm{~nm} / \mathrm{s})$. For each sample, the measurements were performed in mature as well as in newly formed bone tissue. Table 1 shows the number of indentations made in each sample in mature and newly formed bone tissue.

2.6 Statistical Analysis. A one-way analysis of variance (ANOVA) and Tukey-Kramer tests were performed to evaluate (i) the effect of healing time on the indentation modulus and on the hardness and (ii) the difference between mature and newly formed bone tissue.

\section{Results}

Figure 3 shows the histological image of a sample obtained after 7 weeks of healing time. The region located near the implant surface is filled with newly formed bone tissue. Figure 4 shows an image obtained with an optical microscope after the nanoindentation measurements.

The results obtained for the mean values and standard deviations of the measured indentation modulus and hardness for (i) newly formed bone tissue with the three different healing times and (ii) mature bone tissue are shown in Table 2. The mean value of the indentation modulus and of the hardness measured in newly formed bone tissue increases with healing time. The mechanical properties of mature bone are higher than the properties of newly formed bone for the three healing time conditions. ANOVA $\left(p<10^{-5}, F=111.24\right)$ reveals a significant effect of healing time on the indentation modulus of bone tissue. A Tukey-Kramer

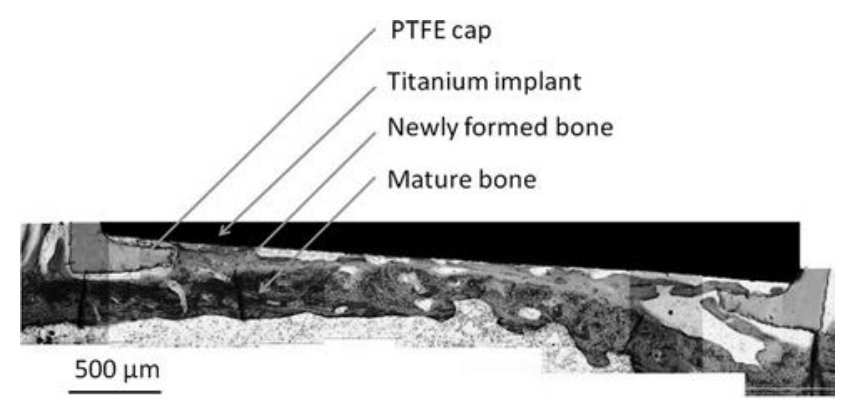

Fig. 3 Image taken after histological preparation. The gray scale corresponds to the degree of mineralization of bone and allows to discriminate newly formed bone tissue (less mineralized, brighter) from mature bone tissue (more mineralized, darker). 


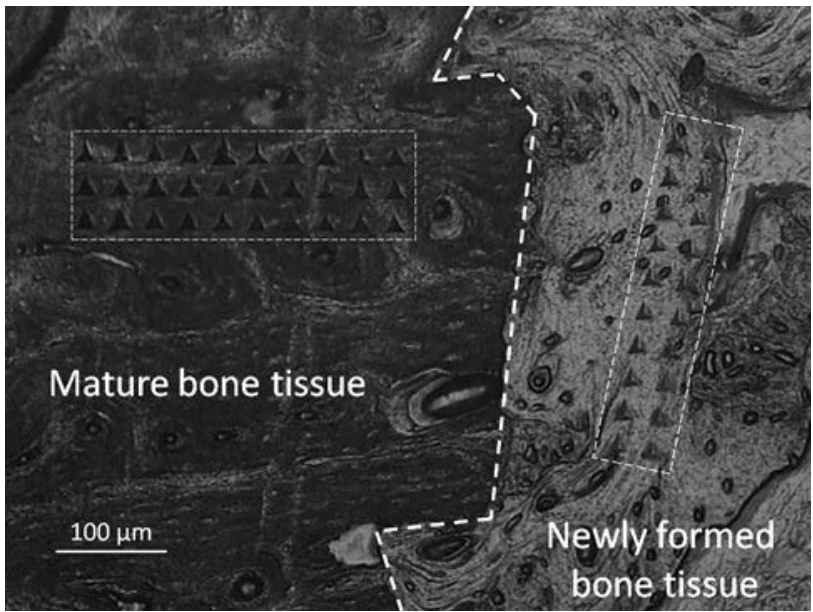

Fig. 4 Image with indents in newly formed and mature bone tissue. The gray scale shows the degree of mineralization of bone and allows to discriminate the two types of bone tissue.

analysis revealed that the values of the indentation moduli of newly formed bone tissue $(4,7$, and 13 weeks) were significantly different from those of mature bone tissue. Moreover, the values of the indentation moduli of newly formed bone tissue at 4 and 7 weeks of healing time are significantly different from those at 13 weeks. However, no significant differences were obtained between a healing time of 4 and 7 weeks. ANOVA $(p=1.65$ $* 10^{-2}, F=3.47$ ) reveals a significant effect of healing time on the hardness of bone tissue. A Tukey-Kramer analysis shows that the values of the hardness of newly formed bone tissue (4 weeks of healing time) are significantly different from those of mature bone tissue. However, no significant differences are obtained between healing times of 4,7 , and 13 weeks.

\section{Discussion}

To the best of our knowledge, the present study is the first one to describe nanoindentation measurements aiming at determining (i) the difference of biomechanical properties between newly formed and mature bone tissue at the vicinity of an implant and (ii) their dependence on healing time.

The orders of magnitude obtained for the indentation moduli and hardness of mature bone tissue are in agreement with previous studies $[19,20]$. Other groups have investigated the indentation modulus in healing bone surrounding a dental implant [12] after one month of healing time. The authors found a gradient of indentation modulus in the direction perpendicular to the implant surface, which gradually increases from $6.17 \mathrm{GPa}$ at a distance lower than $150 \mu \mathrm{m}$ up to $10.13 \mathrm{GPa}$ at a distance of $1500 \mu \mathrm{m}$ from the implant surface. Interestingly, other groups have studied the temporal variation of bone biomechanical properties and mineral content of the external callus during bone healing [48-51], showing that the degree of mineralization of bone (DMB) is an important determinant of the microhardness and indentation modulus of bone tissue. The authors studied the biomechanical properties of newly formed bone tissue in a callus and found similar results since the bone apparent Young's modulus was lower than in newly formed bone tissue and increases as a function of healing time. However, the configuration was different than in the present study since the presence of a biomaterial is likely to influence the evolution of bone properties as a function of healing time.

The results obtained in the present study may be explained by the evolution of (i) the mineralization and (ii) the bone microstructure as a function of healing time. Histological techniques employed in this study allow the qualitative determination of the difference in terms of DMB through the brightness of bone tissue [52]. Mineralized tissue (mature bone tissue) appears darker than less mineralized tissue (newly formed bone tissue). Figure 3 indicates that the $200 \mu$ m thick gap under the implant has been filled with bone tissue, which is brighter than the surrounding mature bone. The results found in this study are consistent with previous studies showing an increase of the elastic modulus with the degree of mineralization of bone tissue [53-55]. The increase in terms of apparent Young's modulus is of the order of $30 \%$ between newly formed and mature bone tissue, which can be explained by Fig. 3 of Ref. [53] showing the prediction of the variation of the elastic coefficients of the ultrastructure as a function of DMB within a wide range of values of DMB. The elastic coefficients are shown to increase nonlinearly with DMB. The results found in Ref. [53] indicate that an increase of the apparent Young's modulus of $30 \%$ approximately corresponds to an increase of DMB from $0.7 \mathrm{~g} / \mathrm{cm}^{3}$ to $1.1 \mathrm{~g} / \mathrm{cm}^{3}$. Moreover, the microstructure of newly formed bone is different from that of mature bone since newly formed bone tissue is often woven bone and has approximately randomly orientated collagen fibers, especially for relatively low healing times [56].

The results of this study may be compared with a previous study of our group [7] realized using micro-Brillouin scattering at a comparable resolution $(10 \mu \mathrm{m})$ in similar samples. The ultrasonic velocity $v$ was measured in mature and newly formed bone tissue ( 7 weeks of healing time). Assuming an isotropic behavior of bone tissue, the indentation modulus may be related to $v$ following:

$$
v=\sqrt{\frac{E}{\rho}}
$$

where $\rho$ is the bone tissue mass density, and $E$ is Young's modulus. The differentiation of Eq. (4) as a function of time leads to

$$
\frac{d \rho}{\rho_{0}}=\frac{d E}{E_{0}}-2 \frac{d v}{v_{0}}
$$

where $\rho_{0}, E_{0}$, and $v_{0}$ are the average values of $\rho, E$, and $v$, respectively, and $d E, d \rho$ and $d v$ correspond to the difference between the values of $\rho, E$, and $v$ in mature and newly formed bone tissue, respectively. Equation (5) leads to a value of $\frac{d \rho}{\rho_{0}}=0.135$, which indicates that bone mass density increases by about $13.5 \%$ between newly formed bone after 7 weeks of healing time and

Table 2 Mean values and standard deviation of the indentation modulus and hardness measured by nanoindentation in newly

\begin{tabular}{|c|c|c|c|c|}
\hline \multicolumn{4}{|c|}{ Newly formed bone tissue } & \multirow{2}{*}{$\frac{\text { Mature bone tissue }}{\text { Mature }}$} \\
\hline Healing time & 4 weeks & 7 weeks & 13 weeks & \\
\hline $\mathrm{E}(\mathrm{GPa})$ & $15.35( \pm 1.81)^{\mathrm{c}, \mathrm{d}}$ & $15.85( \pm 1.55)^{\mathrm{c}, \mathrm{d}}$ & $17.82( \pm 2.10)^{\mathrm{a}, \mathrm{b}, \mathrm{d}}$ & $20.66( \pm 2.75)^{\mathrm{a}, \mathrm{b}, \mathrm{c}}$ \\
\hline $\mathrm{H}(\mathrm{GPa})$ & $0.643( \pm 0.096)^{\mathrm{d}}$ & $0.660( \pm 0.101)$ & $0.668( \pm 0.074)$ & $0.696( \pm 0.150)^{\mathrm{a}}$ \\
\hline
\end{tabular}
formed and mature bone tissue

${ }^{\text {a }}$ Significantly different from 4 weeks group.

bignificantly different from 7 weeks group.

'Significantly different from 13 weeks group.

${ }^{\mathrm{d}}$ Significantly different from Mature group. 
mature bone. The aforementioned increase of $13.5 \%$ of mass density corresponds to the difference of mass density obtained between newly formed bone tissue ( 7 weeks of healing time) and mature bone tissue in the same bone sample. To derive this relative variation of mass density, the results obtained in our previous study using Micro Brillouin scattering technique [7] were used in combination with the results shown herein. The higher mass density of mature bone compared to newly formed bone tissue found herein is due to the higher mineral content. Bone is predominantly made of collagen fibers, minerals, and water. Therefore, an increase in bone mineralization results in a global increase in mass density since mineral is the heaviest bone component.

This study has several limitations. First, only three samples were considered due to the complexity of the surgical procedure, which makes it impossible to consider the scatter of the mechanical properties derived from the experiments. Therefore, special care is needed for the interpretation of the values of such parameters estimated with our method. However, note that the present study compares the biomechanical properties of mature and newly formed bone tissue rather than provide an absolute measurement.

Second, nanoindentation at room temperature under dry conditions shall give different results to wet nanoindentation, as shown by Wolfram et al. [57] in a study investigating the effects of rehydration on the transverse isotropic material properties of vertebral trabecular bone at different locations with a view to different donor specific properties. Here, samples are embedded in methyl methacrylate for histological analyses, so they are in dry conditions. Furthermore, the dry conditions may affect bone of different mineralization levels differently (i.e., the newly formed bone tissue with a greater proportion of organic matrix may be more affected by dry conditions that the mature tissue).

Third, it would have been interesting to use quantitative backscattered scanning electronic microscopy in order to determine quantitatively the degree of mineralization of bone tissue at the indentation sites since it would have allowed quantitative comparison of indentation modulus and hardness as a function of calcium content in the bone [58]. However, we decided to use histology since it is the reference technique in the domain of endosseous implant studies.

Fourth, the coin-shaped implant model used herein is not typical of the clinical situation because the implant is not subjected to any loading. Therefore, the tissue around the implant is lacking the mechanical stimulation, which would be occurring in a loaded implant. This lack of mechanical stimulation may cause a different healing response to the loaded situation.

\section{Conclusions}

A nanoindentation device was used to measure the indentation modulus and hardness in mature and newly formed bone tissue, showing a significant effect of healing time. This study gives further insight on the evolution of the biomechanical properties of newly formed bone tissue at the micrometer scale as a function of healing time. The results might lead to a better understanding of the clinical evolution of titanium implant after surgery.

\section{Acknowledgment}

The authors acknowledge the support of the Direction de la Recherche de l'UPEC. The authors acknowledge the support of the Direction Générale de l'Armement and of the Centre National de la Recherche Scientifique through the Ph.D. study of VM. This work has been supported by French National Research Agency (ANR) through EMERGENCE program (project WaveImplant No. ANR-11-EMMA-039) and by the Centre Francilien de l'Innovation and OSEO through the Aima Laboratoire funding.

\section{References}

[1] Franchi, M., Bacchelli, B., Giavaresi, G., De Pasquale, V., Martini, D., Fini, M., Giardino, R., and Ruggeri, A., 2007, "Influence of Different Implant Surfa- ces on Peri-Implant Osteogenesis: Histomorphometric Analysis in Sheep," J. Periodontol., 78(5), pp. 879-888

[2] Luo, G. M., Sadegh, A. M., Alexander, H., Jaffe, W., Scott, D., and Cowin, S. C., 1999, "The Effect of Surface Roughness on the Stress Adaptation of Trabecular Architecture Around a Cylindrical Implant," J. Biomech., 32(3), pp. 275-284.

[3] Mori, S., and Burr, D. B., 1993, "Increased Intracortical Remodeling Following Fatigue Damage," Bone, 14(2), pp. 103-109.

[4] Orlik, J., Zhurov, A., and Middleton, J., 2003, "On the Secondary Stability of Coated Cementless Hip Replacement: Parameters That Affected Interface Strength," Med. Eng. Phys., 25(10), pp. 825-831.

[5] Duyck, J., Vandamme, K., Geris, L., Van Oosterwyck, H., De Cooman, M., Vandersloten, J., Puers, R., and Naert, I., 2006, "The Influence of MicroMotion on the Tissue Differentiation Around Immediately Loaded Cylindrical Turned Titanium Implants," Arch. Oral Biol., 51(1), pp. 1-9.

[6] Winter, W., Heckmann, S. M., and Weber, H. P., 2004, "A Time-Dependent Healing Function for Immediate Loaded Implants," J. Biomech., 37(12), pp. 1861-1867.

[7] Mathieu, V., Fukui, K., Matsukawa, M., Kawabe, M., Vayron, R., Soffer, E., Anagnostou, F., and Haiat, G., 2011, "Micro-Brillouin Scattering Measurements in Mature and Newly Formed Bone Tissue Surrounding an Implant," J. Biomech. Eng., 133, 021006.

[8] Mathieu, V., Anagnostou, F., Soffer, E., and Haiat, G., 2010, "Ultrasonic Evaluation of Dental Implant Biomechanical Stability: An in vitro Study," Ultrasound Med. Biol., 37(2), pp. 262-270.

[9] Mathieu, V., Vayron, R., Barthel, E., Dalmas, D., Soffer, J. E., Anagostou, F., and Haiat, G., 2012, "Mode III Cleavage of a Coin-Shaped Titanium Implant in Bone: Effect of Friction and Crack Propagation," J. Mech. Behav. Biomed. Mater., 8, pp. 194-203.

[10] Mathieu, V., Anagnostou, F., Soffer, E., and Haiat, G., 2011, "Numerical Simulation of Ultrasonic Wave Propagation for the Evaluation of Dental Implant Biomechanical Stability," J. Acoust. Soc. Am., 129(6), pp. 4062-4072.

[11] Mathieu, V., Soffer, J. E., Anagnostou, F., and Haïat, G., 2012, "Influence of Healing Time on the Ultrasonic Response of the Bone-Implant Interface," Ultrasound Med. Biol., (in press).

[12] Chang, M. C., Ko, C. C., Liu, C. C., Douglas, W. H., DeLong, R., Seong, W. J. Hodges, J., and An, K. N., 2003, "Elasticity of Alveolar Bone Near Dental Implant-Bone Interfaces After one Month's Healing," J. Biomech., 36(8), pp. 1209-1214.

[13] Seong, W. J., Kim, U. K., Swift, J. Q., Hodges, J. S., and Ko, C. C., 2009 "Correlations Between Physical Properties of Jawbone and Dental Implant Initial Stability," J. Prosthet. Dent., 101(5), pp. 306-318.

[14] Ronold, H. J., and Ellingsen, J. E., 2002, "The Use of a Coin Shaped Implant for Direct in Situ Measurement of Attachment Strength for Osseointegrating Biomaterial Surfaces," Biomaterials, 23(10), pp. 2201-2209.

[15] Ronold, H. J., Ellingsen, J. E., and Lyngstadaas, S. P., 2003, "Tensile Force Testing of Optimized Coin-Shaped Titanium Implant Attachment Kinetics in the Rabbit Tibiae," J. Mater. Sci.: Mater. Med., 14(10), pp. 843-849.

[16] Ronold, H. J., and Ellingsen, J. E., 2002, "Effect of Micro-Roughness Produced by TiO2 Blasting - Tensile Testing of Bone Attachment by Using Coin-Shaped Implants," Biomaterials, 23(21), pp. 4211-4219.

[17] Ronold, H. J., Lyngstadaas, S. P., and Ellingsen, J. E., 2003, “A Study on the Effect of Dual Blasting With Tio(2) on Titanium Implant Surfaces on Functional Attachment in Bone," J. Biomed. Mater. Res. Part A, 67A(2), pp. 524-530.

[18] Ronold, H. J., Lyngstadaas, S. P., and Ellingsen, J. E., 2003, "Analysing the Optimal Value for Titanium Implant Roughness in Bone Attachment Using a Tensile Test," Biomaterials, 24(25), pp. 4559-4564.

[19] Zysset, P. K., 2009, "Indentation of Bone Tissue: A Short Review," Osteoporosis Int., 20(6), pp. 1049-1055.

[20] Lewis, G., and Nyman, J. S., 2008, "The Use of Nanoindentation for Characterizing the Properties of Mineralized Hard Tissues: State-Of-The Art Review," J. Biomed. Mater. Res., Part B: Appl. Biomater., 87B(1), pp. 286-301.

[21] Shibata, Y., He, L. H., Toda, Y., Kataoka, Y., Fujisawa, N., Miyazaki, T., and Swain, M. V., 2008, "Micromechanical Evaluation of Mineralized Multilayers," J. Biomech., 41(16), pp. 3414-3418.

[22] Hoffler, C. E., Moore, K. E., Kozloff, K., Zysset, P. K., Brown, M. B., and Goldstein, S. A., 2000, "Heterogeneity of Bone Lamellar-Level Elastic Moduli," Bone, 26(6), pp. 603-609.

[23] Rho, J. Y., Zioupos, P., Currey, J. D., and Pharr, G. M., 1999, "Variations in the Individual Thick Lamellar Properties Within Osteons by Nanoindentation," Bone, 25(3), pp. 295-300.

[24] Rho, J. Y., Zioupos, P., Currey, J. D., and Pharr, G. M., 2002, "Microstructural Elasticity and Regional Heterogeneity in Human Femoral Bone of Various Ages Examined by Nano-Indentation," J. Biomech., 35(2), pp. 189-198.

[25] Hengsberger, S., Ammann, P., Legros, B., Rizzoli, R., and Zysset, P., 2005, "Intrinsic Bone Tissue Properties in Adult Rat Vertebrae: Modulation by Dietary Protein," Bone, 36(1), pp. 134-141.

[26] Norman, J., Shapter, J. G., Short, K., Smith, L. J., and Fazzalari, N. L., 2008 "Micromechanical Properties of Human Trabecular Bone: A Hierarchical Investigation Using Nanoindentation,” J. Biomed. Mater. Res. Part A, 87A(1), pp. 196-202.

[27] Zysset, P. K., Guo, X. E., Hoffler, C. E., Moore, K. E., and Goldstein, S. A., 1999, "Elastic Modulus and Hardness of Cortical and Trabecular Bone Lamellae Measured by Nanoindentation in the Human Femur," J. Biomech., 32(10), pp. $1005-1012$.

[28] Gupta, H. S., Stachewicz, U., Wagermaier, W., Roschger, P., Wagner, H. D. and Fratzl, P., 2006, "Mechanical Modulation at the Lamellar Level in Osteonal Bone," J. Mater. Res., 21(8), pp. 1913-1921. 
[29] Hofmann, T., Heyroth, F., Meinhard, H., Franzel, W., and Raum, K., 2006, "Assessment of Composition and Anisotropic Elastic Properties of Secondary Osteon Lamellae," J. Biomech., 39(12), pp. 2282-2294.

[30] Hoc, T., Henry, L., Verdier, M., Aubry, D., Sedel, L., and Meunier, A., 2006, "Effect of Microstructure on the Mechanical Properties of Haversian Cortical Bone," Bone, 38(4), pp. 466-474.

[31] Sohn, J.-Y., Park, J.-C., Um, Y.-J., Jung, U.-W., Kim, C.-S., Cho, K.-S., and Choi, S.-H., 2010, "Spontaneous Healing Capacity of Rabbit Cranial Defects of Various Sizes," J. Periodontal Implant Sci., 40(4), pp. 180-187.

[32] Baker, M. I., Eberhardt, A. W., Martin, D. M., McGwin, G., and Lemons, J. E., 2010, "Bone Properties Surrounding Hydroxyapatite-Coated Custom Osseous Integrated Dental Implants,” J. Biomed. Mater. Res., Part B: Apple Biomater., 95B(1), pp. 218-224.

[33] Maimoun, L., Brennan, T. C., Badoud, I., Dubois-Ferriere, V., Rizzoli, R., an Ammann, P., 2010, "Strontium Ranelate Improves Implant Osseointegration," Bone, 46(5), pp. 1436-1441.

[34] Ballarre, J., Manjubala, I., Schreiner, W. H., Orellano, J. C., Fratzl, P., and Cere, S., 2009, "Improving the Osteointegration and Bone-Implant Interface by Incorporation of Bioactive Particles in Sol-Gel Coatings of Stainless Steel Implants," Acta Biomater., 6(4), pp. 1601-1609.

[35] Viceconti, M., Monti, L., Muccini, R., Bernakiewicz, M., and Toni, A., 2001, "Even a Thin Layer of Soft Tissue May Compromise the Primary Stability of Cementless Hip Stems," Clin. Biomech. (Bristol, Avon), 16(9), pp. 765-775.

[36] Viceconti, M., Brusi, G., Pancanti, A., and Cristofolini, L., 2006, "Primary Stability of an Anatomical Cementless Hip Stem: A Statistical Analysis " J. Biomech., 39(7), pp. 1169-1179.

[37] Chevallier, N., Anagnostou, F., Zilber, S., Bodivit, G., Maurin, S., Barrault, A., Bierling, P., Hernigou, P., Layrolle, P., and Rouard, H., 2009, "Osteoblastic Differentiation of Human Mesenchymal Stem Cells With Platelet Lysate," Biomaterials, 31(2), pp. 270-278.

[38] Soffer, E., Ouhayoun, J. P., Meunier, A., and Anagnostou, F., 2006, "Effects of Autologous Platelet Lysates on Ceramic Particle Resorption and New Bone Formation in Critical Size Defects: The Role of Anatomical Sites," J. Biomed. Mater. Res., Part B: Appl. Biomater., 79B(1), pp. 86-94.

[39] Oliver, W. C., and Pharr, G. M., 1992, "An Improved Technique for Determining Hardness and Elastic-Modulus Using Load and Displacement Sensing Indentation Experiments," J. Mater. Res., 7(6), pp. 1564-1583.

[40] Oyen, M. L., 2006, "Nanoindentation Hardness of Mineralized Tissues," J. Biomech., 39(14), pp. 2699-2702.

[41] Sakai, M., 1999, "The Meyer Hardness: A Measure for Plasticity?," J. Mater Res., 14(9), pp. 3630-3639.

[42] Oliver, W. C., and Pharr, G. M., 2004, "Measurement of Hardness and Elastic Modulus by Instrumented Indentation: Advances in Understanding and Refinements to Methodology," J. Mater. Res., 19(1), pp. 3-20.

[43] Rupin, F., Saïed, A., Dalmas, D., Peyrin, F., Haupert, S., Raum, K., Barthel, E., Boivin, G., and Laugier, P., 2009, "Assessment of Microelastic Properties of Bone Using Scanning Acoustic Microscopy: A Face-to-Face Comparison With Nanoindentation," J. Clin. Densitom., 12(1), p. 126.

[44] Brennan, O., Kennedy, O. D., Lee, T. C., Rackard, S. M., and O’Brien, F. J., 2009, "Biomechanical Properties Across Trabeculae From the Proximal Femur of Normal and Ovariectomised Sheep," J. Biomech., 42(4), pp. 498-503.
[45] Li, X., and Bhushan, B., 2002, "A Review of Nanoindentation Continuous Stiffness Measurement Technique and its Applications Next Term," Mater. Charact., 48(1), pp. 11-36.

[46] Shen, L., Wang, L., Liu, T. X., and He, C. B., 2006, "Nanoindentation and Morphological Studies of Epoxy Nanocomposites," Macromol. Mater. Eng., 291(11), pp. 1358-1366.

[47] Wang, X., Allen, M., Burr, D., Lavernia, E., Jeremić, B., and Fyhrie, DP, 2008 "Identification of Material Parameters Based on Mohr-Coulomb Failure Criterion for Bisphosphonate Treated Canine Vertebral Cancellous Bone," Bone, 43(4), pp. 775-780.

[48] Manjubala, I., Liu, Y., Epari, D. R., Roschger, P., Schell, H., Fratzl, P., and Duda, G. N., 2009, "Spatial and Temporal Variations of Mechanical Properties and Mineral Content of the External Callus During Bone Healing," Bone, 45(2), pp. 185-192.

[49] Leong, P. L., and Morgan, E. F., 2008, "Measurement of Fracture Callus Material Properties via Nanoindentation," Acta Biomater., 4(5), pp. $1569-1575$.

[50] Leong, P. L., and Morgan, E. F., 2009, "Correlation Between Nanoindentation Modulus and Mineral Density in Fracture Callus Tissues," Proceedings of the ASME Summer Bioengineering Conference 2008, Parts A and B, ASME, New York, pp. 675-676.

[51] Ishimoto, T., Nakano, T., Yamamoto, M., and Tabata, Y., 2011, "Biomechanical Evaluation of Regenerating Long Bone by Nanoindentation," J. Mater. Sci.: Mater. Med., 22(4), pp. 969-976.

[52] Artzi, Z., Givol, N., Rohrer, M. D., Nemcovsky, C. E., Prasad, H. S., and Tal, H., 2003, "Qualitative and Quantitative Expression of Bovine Bone Mineral in Experimental Bone Defects. Part 2: Morphometric Analysis," J. Periodontol., 74(8), pp. 1153-1160.

[53] Sansalone, V., Naili, S., Bousson, V., Bergot, C., Peyrin, F., Zarka, J., Laredo, J. D., and Haiat, G., 2010, "Determination of the Heterogeneous Anisotropic Elastic Properties of Human Femoral Bone: From Nanoscopic to Organ Scale," J. Biomech., 43(10), pp. 1857-1863.

[54] Hodgskinson, R., Currey, J. D., and Evans, G. P., 1989, "Hardness, an Indicator of the Mechanical Competence of Cancellous Bone," J. Orthop. Res., 7(5), pp. 754-758.

[55] Sansalone, V., Bousson, V., Naili, S., Bergot, C., Peyrin, F., Laredo, J. D., and Haïat, G., 2012, "Anatomical Distribution of the Degree of Mineralization of Bone Tissue in Human Femoral Neck: Impact on Biomechanical Properties," Bone, (in press).

[56] Matos, M. A., Araujo, F. P., and Paixao, F. B., 2008, "Histomorphometric Evaluation of Bone Healing in Rabbit Fibular Osteotomy Model Without Fixation,' J. Orthop. Surg., 3, p. 4.

[57] Wolfram, U., Wilke, H. J., and Zysset, P. K., 2010 "Rehydration of Vertebral Trabecular Bone: Influences on its Anisotropy, its Stiffness and the Indentation Work With a View to Age, Gender and Vertebral Level," Bone, 46(2), pp. 348-354.

[58] Fratzl-Zelman, N., Roschger, P., Gourrier, A., Weber, M., Misof, B. M., Loveridge, N., Reeve, J., Klaushofer, K., and Fratzl, P., 2009, "Combination of Nanoindentation and Quantitative Backscattered Electron Imaging Revealed Altered Bone Material Properties Associated With Femoral Neck Fragility," Calcif. Tissue Int., 85, pp. 335-343. 